\title{
SEJARAH DAN DAKWAH INSTITUSI PENDIDIKAN TINGGI ISLAM AWAM (IPTA) DI PATTANI THAILAN SELATAN
}

\section{Abdulrasyid Bin Hassan' ${ }^{\text {, Mahsidi Salae }}{ }^{2}$, Muhammad Azhar Zailani³, Ghazali Darusalam ${ }^{4}$}

\begin{abstract}
This paper attempts to look at the history of the establishment of an Islamic high institution based on the spirit of mutual understanding, unification, and cooperation in the process of strategic planning of Muslims in Southern Thailand. This paper is also to show that the teachings of Islam and its colleges are comprehensive (syumul) and not all that brought by modernized currents are rejected by Islam. The purpose of this study in addition to analyzing the history of the establishment of Islamic university institutions in Southern Thailand, the author tries to read the history of the establishment of an Islamic higher education institution in Pattani, to impact the history of manifestation and development in the field of Islamic universities that became the basic for the construction of muslims realized in the program and aspect of socio-economic reform of the ummah which is also part of Islamic dakwah. This review will examine the history of Islamic education grow that occurred at the Islamic University of Islamic College Songkla Nakharin University Pattani South Thailand. As such, this review will be an important guide and reference for colleges, Islamic college centers and institutions of Islamic universities in Thailand and especially the Islamic College of Islamic University of Songkla Nakharin University Pattani campus, Thailand.
\end{abstract}

Keywords: Institution, higher education

\begin{abstract}
Abstrak: Makalah ini mencoba melihat sejarah pendirian institusi tinggi Islam berdasarkan semangat permuafakatan, penyatuan, dan kerjasama dalam proses rencana strategi orang-orang Islam di Selatan Thailand. Makalah ini juga untuk menunjukkan bahwa ajaran Islam dan perguruannya itu komprehensif (syumul) dan tidak semua yang dibawa oleh arusmedernisasi itu ditolak oleh Islam. Tujuan dari kajian ini selain untuk menganalisis sejarah pendirian institusi perguruan tinggi Islam di Selatan Thailand, penulis mencoba membaca sejarah pendirian sebuah institusi pendidikan tinggi Islam di Pattani, untuk mengimbas

\footnotetext{
1 Mahasiswa S3 Falsafah Pendidikan Universiti Malaya, KualaLumpur, Malaysia. Email: abdulrashid_hsn@gmail.com

${ }^{2}$ Dosen di Jabatan Pendidikan Islam, Fakulti Pendidikan, Universiti Fatoni,Thailand. Email: mahsidi@yahoo.com

${ }^{3}$ Dosen di Jabatan Pendidikan Bahasa dan Literasi, Fakulti Pendidikan,Universiti Malaya, Kuala Lumpur Malaysia. Email: azharzailani@yahoo.com

${ }^{4}$ Dosen di Jabatan Dasar Pendidikan dan Kemanusiaan, Fakulti Pendidikan, Universiti Malaya, Kuala Lumpur Malaysia. Email: gazalidarus@gmail.com
} 
kembali kepada sejarah pewujudan dan pembangunan dalam bidang perguruan Islam yang menjadi dasar kepada pembangunan umat Islam untuk direalisasikan dalam program danaspek pembaruan sosial ekonomi ummat yang juga merupakan bagian dari dakwah Islamiyah. Kajian ini akan meneliti sejarah pendidikan Islam berotonomi yang terjadi di Kolej Perguruan Islam Universitas Songkla Nakharin Kampus Pattani Selatan Thailand. Dengan itu, kajian ini akan menjadi panduan dan rujukan penting untuk kolej-kolej, pusat-pusat perguruan tinggi Islam dan institusi-institusi perguruan tinggi Islam di Thailand dan khususnya Kolej Perguruan Islam Universitas Songkla Nakharin kampus Pattani, Thailand.

Katakunci: Institusi, pendidikan tinggi

\section{Pendahuluan}

Sejarah pendidikan Islam di Selatan Thailand merupakan sejarah yang panjang seiring dengan munculnya Islam sejak 1437 tahun yang lalu, dalam usaha untuk melaksanakan program Pendidikan yang cemerlang, suatu sistem yang teratur dan kurikulum yang terpadu amat diperlukan. Islam amat menekankan kepentingan apa saja yang mempunyai kaitan dengan pendidikan dan memupuk kerohanian manusia. Objektif utama pendidikan Islam adalah untuk melahirkan manusia yang baik dan beriman supaya ia dapat menjalankan corak kehidupan yang sejahtera dan berhasil di dunia serta mencapai kesejahteraan dan kebahagiaan di akhirat (Noor Hisham, 2011). Segala prinsip dan peraturan yang menyusun kehidupan seorang manusia tidak hanya terserah kepada takdir dan kebijaksanaan berfikir semata-mata. Sebaliknya, kehidupan manusia sebenar ditentukan oleh peraturan Allah s.w.t seperti yangtermaktub di dalam alQur'an, Firman Allah SWT, yang artinya:

Dan tidak seekorpun binatang yang melata di bumi, dan tidak seekorpun burung yang terbang dengan kedua sayapnya, melainkan mereka ummat-ummat seperti kamu. Tiada Kami tinggalkan sesuatu pun di dalam kitab al-Quran ini; kemudian mereka semuanya akan dihimpunkan kepada Tuhan mereka (untuk dihisab dan menerima balasan) (al-An'am, 6: 38).

Oleh karena pendidikan merupakan sarana yang amat penting untuk memandu kehidupan manusia kearah mencapai tujuan kecemerlangan, maka segala pendidikan dan pengajaran mestilah dirujuk kepada Islam. Manyadari hakikat sistem pendidikan asing telah gagal menyediakan pendidikan yang sesuai dengan fitrah setiap anggota masyarakat seperti yang dianjurkan oleh Islam (Nurazmallail Murni \& rakan, 2008). Dalam hal ini, segala fenomena yang menJuniJunig kegemilangan ilmu dalam sejarah dan peradaban Islam generasi awal perlu dihayati dan dijadikan dasar panduan terutamanya ketika 
menghadapi tantangan dunia tanpa batas masa kini, sejarah yang gemilang tidak hanya bersifat nostalgia semata-mata, tetapiperlu diulangi padamasa kini dan akan datang.

Sejarah pendidikan merupakan salah satu faktor budaya yang paling penting yang telah dan tetap akan mempengaruhi falsafah pendidikan baik objektif mahupun sistemnya, keperibadian nasional, walaupun sistemnya adalah hasil dari pemerintahan revolusi yang didirikannya dengan sengaja untuk mengembangkan dan membaiki pola-pola warisan budaya umat dan rakyat lampau. Oleh karena, warisan budaya suatu bangsa sukar dihapuskan dengan serta-merta (Mursi, 1974).

Meneliti sejarah perkembangan pendidikan Islam adalah suatu usaha yang amat penting. Penghayatan terhadap hal ini dapat memberi ruang untuk menganalisis kemajuan dan kecemerlangan umat Islam yang dicapai melalui proses pendidikannya. Institusi adalah istilah yang meluas penggunaannya dalam bidang sosiologi. Istilah ini merujuk kepada suatu pola kegiatan sesuatu kelompok sosial, dengan melalui kegiatan tersebut akan membentuk struktur sosial. Institusi ialah sistem atau peraturan yang bersifat abstrak atau mujarrad dan merupakan konsep yang terdiri dari kod, norma, atau ideologi baik tbertulis atau tidak. Sejarah institusi perguruan tinggi Islam dalam konteks pendidikan merupakan sejarah perjuangan bukanlah hal yang mudah, lebih-lebih lagi di sebidang tanah yang telah dijajah di bawah pemerintahan kolonial Siam. Sejarah pendidikan Islam di Selatan Thailand munculnyanya seiring dengan usia Islam itu sendiri sejak 1437 tahun. Sejarah timbulnya dan perkembangan institusi perguruan tinggi Islam di Patani dapat dirumuskan dari sistem pendidikan tradisional bercorak pondok, madrasah, maahad dan sekolah aliran agama, untuk menampung kelompok yang berpendidikan tinggi serta desakkan masyarakat setempat. Institusi pendidikan tinggi Islam bisa digolongkan kepada dua, ialah Institusi Perguruan Tinggi Islam Negeri (kerajaan) dan Institusi Perguruan Tinggi Islam Swasta (IPTS) maka pada tahun 1971 dimulai lembaran catatan sejarah institusi perguruan tinggi Islam negeri di Patani di bawah Kolej Perguruan Islam Universitas Songkla Nakharin. Gagasan struktur menejemen konkrit dapat dibagi kepada tiga bagian adalah: i. pejabat pemerintahan dan menejemen, ii. bidang khidmat masyarakat, dan iii. pusat menejemen akademik perguruan Islam. Rencana pembangunan pelaksanaan dan kemajuan dapat dibagi kepada tiga tahap ialah: pertama dasar pembangunan dimulai pada tahun 1972, dimulai peletakan batu pertama pendirian bangunan kolej, pada tahun 1974 kedatangan melawat kerangka kerjasama dalam program perguruan Islam. Pembagunan kemajuan tahap kedua ialah perencanaan pembangunan kemajuan untuk menjadi sebuah kolej perguruan Islam, ini dimulai pada tahun 1982 pelaksanaan rencana strategi dimulai pada pertengahan tahun 1981, dimulai ijazah sarjana muda perguruan Islam di bawah fakultas kemanusiaan dan ilmu sosial, pada tahun 1994, dimulai 
perguruan ijazah sarjana muda perguruan Islam, pada tahun 1997, dimulai perguruan ijazah sarjana muda undang-undang Islam pada tahun 1998, dimulai ijazah sarjana perguruan Islam. Pada tahun 2000, dimulai ijazah sarjana muda dalam bidang perguruan Islam (Program Bahasa Arab), pada tahun 2002, dimulai projek pengukuhan bidang perguruan Islam. Pada tahun 2002 juga, dimulai perguruan ijazah sarjana muda ekonomi dan menejemen dalam Islam. Dan tahap ke-tiga ialah memertabatkan dan meluaskan lagi bidang-bidang perguruan lain dan usaha internasionalisasi institusi ini dimulai pada tahun 2004 dengan projek kajian strategi wilayah berhubung perguruan Islam. Pada tahun 2005, dimulai perguruan sarjana muda bidang perguruan Timur Tengah. Pada tahun 2006, dimulai perguruan Doktor (Ph.D), dalam bidang Perguruan Islam dan pada tahun 2007, permulaan perguruan sarjana muda bidang perguruan Islam dalam programInternasional. Makalah ini juga untuk menunjukkan bahwa ajaran Islam dan perguruannya itu komprehensif (syumul) dan tidak semua yang dibawa oleh arus pemodernan itu ditolak oleh Islam.

\section{Institusi Perguruan Tinggi Islam Pattani}

Sejarah perkembangan institusi pendidikan tinggi dapat dirumuskan bahwa madrasah ialah hasil evolusi atau susulan dari tiga tahap perkembangan institusi pendidikan Islam, yaitu: i. Masjid Jamik (The Cathedral Mosque) sejak abad pertama Hijriah, ii. Masjid Khan (Mosque-College) dengan menyediakan penempatan asrama dimulai pada abad ke-10, dan iii. Madrasah yang wujud sejak abad ke-4 hingga abad ke-5 Hijriah atau abad ke-10 hingga abad ke-11, kedua-dua institusi jamik dan masjid mempunyai fungsi dan kedudukan yang sukar dipisahkan dan keadaan ini berterusan dalam suatu jangka masa yang agak lama (Ibn Kathir,1981; Ibn al-Jawzi, 1992).

Sejarah pendirian institusi pendidikan Islam dapat dibagi kepada dua kategori, ialah : i. institusi yang di duuong oleh ideal tradisional pada abad ke-5 Hijriah atau 11 Masehi, ii. institusi yang didorong oleh ideal rasional seperti Bayt al-Hikmah pada abad ke-tiga (Maksidi, 1981). Justeru, penginstitusian ilmu yang dilihat melalui pendirian institusi Islam wajar dilihat secara terpadu dengan mengharmonikan dua kategori ilmu, yaitu ilmu naqli (wahyu) dan ilmu aqli sebagai ilmu dasar. Munculnya institusi pendidikan dalam sejarah peradaban Islam jelas membuktikan tentang perkembangan pesat aktivitas keilmuan dalam masyarakat Islam pada masa tersebut.

Pattani merupakan pusat peradaban yang terkenal pada masa silam, karena telah ada kerajaan yang berdaulat dan mempunyai sistem politik yang tersusun. Lantaran itu, terjadi kemajuan yang pesat dalam bidang ilmu pengetahuan hingga dikenali dengan julukan serambi Mekah (Nik Anuar, 1999). Sebuah institusi yang unggul ialah yang memainkan tiga peranan utama yaitu: untuk melahirkan kelompok para sarjana dan ilmuwan, untuk menjalankan penyelidikan untuk mencari ilmu kebenaran dan untuk menjadi pemimpin dalam memanfaatkan ilmu untuk pembangunan masyarakat. 
Universitas pada masa ini umpama sebuah gedung besar dengan program, kursus, dan perkhidmatan yang berbagai. Justeru, ini sebagian dari petanda bahwa universitas tidak lagi bersifat elitis. Bahkan bersifat demokratis dan terbuka. Universitas sebagai menara gading hanyalah satu kenangan zaman silam. bahkan kini sudah menjadi megaversiti dengan jumlah mahasiswa yang banyak (Sufean Hussin, 1995). Fokus utama Universitas dan institut masa kini ialah pembangunan ekonomi, sosial, dan teknologi yang dapat memenuhi konsep industri, persaingan dan globalisasi.

Sejarah membuktikan, institusi pendidikan tinggi bisa berubah falsafah, fokus dan wajahnya, apabila masyarakat berubah, atau apabila kuasa-kuasa luar memberi tekanannya terhadap urusan pemerintahan dan akademik universitas. Ini adalah karena universitas ialah sebagian dari entiti masyarakat. Walau bagaimanapun, masih terdapat perbedaan dari segi falsafah dan fungsi pendidikan tinggi, yang mencerminkan dilema pemikiran para sarjana dalam proses sejarah evolusi pendidikan tinggi dari zaman klasik, penyinaran, dan pragmatik.

Dari segi sejarahnya, Universitas menjadi mercu tanda sesebuah peradaban dan instrument dalam proses pembangunan masyarakat dan negara, khususnya dari segi intelektual, teknologi, dan perindustrian. Masyarakat yang tidak mempunyai universitas ialah masyarakat yang mundur. Ini satu hakikat yang nyata. Negara-negara Barat yang telah meminjam ide universitas dari masyarakat Islam Timur Tengah pada abad kesembilan, terus kukuh mempercayai fungsi penting universitas dalam pemerintahan kerajaan dan melahirkan ilmu baru. Masyarakat Barat terus gigih menguatkan dan mengembangkan universitas mereka dengan berbagai disiplin ilmu sains dan bukan sains, dan mereka juga terus gigih menimbailmu baru melalui kegiatan penyelidikan.

Institusi Perguruan Tinggi Islam Pattani adalah lambang keagungan peradaban Islam di rantau ini, munculnya dari sistem pendidikan tradisional bercorak pondok, madrasah, ma'had dan sekolah aliran agama, untuk menampung kelompok yang berpendidikan tinggi serta desakan masyarakat setempat maka pada tahun 1971 dimulai lembaran catatan sejarah institusi perguruan Islam di Pattani (Mohd. Lazim Lawee, 2007). Maka pendirian IPT ini sebagai batu loncatan yang terbuka luas untuk anak-anak Melayu di peribumi Pattani untuk menimba ilmu pengetahuan. Evolusi pendidikan tinggi di dunia hari ini dari peradaban telah membawa penegasan pendidikan tinggi kepada pencarian ilmu hakiki. Peradaban Islam pada abad ke-8 dan abad ke-13 telah membawa sumbangan besar dan mempunyai makna terhadap pendidikan tinggi.

Perizinan untuk pendirian IPT Islam di Thailand elemen perlembagaan undang-undang Thailand menjadi hak tuntutan, menurut elemen perundangan 2540bd 1997 pada bab III akta 38 (Noukhong \& rakan-rakan, 2003) yang mencatatkan kebebasan beragama secara mutlak untuk menganut dan 
berpegang dengan mana-mana agama, dan hak kebebasan melakukan ibadat dengan apapun selagi tidak bertentangan dengan undang-undang negara dan mengganggu hak-hak orang lain (Muslimin Thailand, 2005).

Isu-isu di wilayah-wilayah Selatan Thai seperti politik dan pergolakan tidak nampak noktah akhir yang diselitkan dengan beberapa puak pemisah dan juga fahaman kaum tua dan kaum baru yang sering memukau ideologi masingmasing, apabila politik tidak tenteram dan isu-isu agama didebatkan maka masyarakat tidak aman dan agenda lain akan terjadi akibat dari punca tersebut, termasuk ekonomi, sosial dan yang paling jelas sekali dalam bidangpendidikan.

Dengan itu, terjadilah desakan dan tuntutan yang perlu segera ditangani dan diatasi, di antara tindakan untuk mengatasi masalah-masalah membangunkan bidang pendidikan yang dapat dikatakan sebagai kunci penting dalam mengatasi isu-isu yang dilanda dalam bentuk jangka masa Panjang. Menurut statistik jumlah buta huruf di kalangan penduduk di wilayah-wilayah ini amat tinggi kalau dibandingkan dengan wilayah-wilayah lain, dan pelajar berkelulusan universitas paling rendah, dan undang-undang penyelenggaraan baik peringkat sosial dan pendidikan tidak sesuai dengan penduduk Islam setempat. Aliran sekolah pemerintah langsung tidak diajar silibus agama yang menjadi panduan hidup keseharian mereka, sedangkan pondok-pondok dan madrasah-madrasah yang menjadi pilihan dan harapan kepada rakyat tidak diakui oleh badan-badan tertentu serta tidak ada institusi di peringkat tinggi yang mengakui dan berkualitas, lembaga penyelaras pendidikan Islam kurang memberi kepentingan, lembaga buku teks dan kurikulum pendidikan Islam kurang memainkan peranan, dan pusat-pusat latihan guru Islam belum lagi dibangun (Mohd ZamberiA. Malek, 1994).

Maka hasil dari kesadaran dan kesungguhan para ulama cendekiawan, murabbi tulus ikhlas dan ilmuan yang cerdik, serta keberanian mereka untuk mempertahankan dan mengembangkan ajaran Islam, maka pendidikan Islam semakin subur dan aktif. Institusi perguruan tinggi Islam di Selatan Thailand dapat dibagi kepada dua jenis; ialah institusi perguruan tinggi Islam Awam (IPTA) dan institusi perguruan tinggi Islam swasta (IPTS). Menurut sejarah, institusi perguruan tinggi Islam swasta lebih awal pendiriannya sekalipun belum mendapat pengakuan dari pihak kerajaan (Ibrahim Narung raksakit \& Numan Hajimasae, 2010). Modernisasi perguruan tinggi Islam kerajaan dapat dibagi kepada dua tahap menurut masa ialah: tahap pertama dimulai pada tahun 1974 hingga 1980 sebagai salah satu mata pelajaran teras dan dasar di bawah perguruan sains sosial dan kemanusiaan Universitas Songkla Nakharin Pattani dan tahap kedua ialah dimulai tahun 1989 Hingga 1989 sebagai tempuh masa modernisasi pembangunan dan tahap pendirian menjadi sebuah kolej perguruan tinggi Islam setanding fakultas di bawah Universitas Songkla Nakharin. Fakultas sains sosial dan kemanusiaan Universitas Songkla Nakharin ada perencanaan untuk dibuka bidang perguruan Islam semenjak awal pendirian tersebut, untuk menambahkan lagi satu saluran kefahaman di segi pengetahuan 
agama, fakultas adab budaya dan memajukan lagi ekonomi masyarakat penduduk setempat kearah yang lebih maju danterbaik (Seminar Akademik Islam, 1985).

Kepentingan dan keperluang sebuah institusi perguruan tinggi Islam di Pattani, kewujudannya adalah menjadi kelaziman untuk menampung keperluan pelajar yang tidak mampu dan tidak wujud kesempatan belajar di luar negara. Di antara institusi perguruan tinggi Islam ialah; Maahad al-Idad al-Islamiy tajaan Mjlis Agama Islam Yala, Kulliah Sore di Cherang Batu, Pattani, Kulliyah Syeikh Daud al-Fatani, Kedai Buruk, Yala, Kulliah Imam Syafi'e, Jaha, Yala, dan Maahad al-Ali al-Dirasat al-Islamiyat wa al-Arabiyaat (MADIWA), Peta, Jaha, Yala. Bagaimanapun, IPT Islam yang mendapat pengakuan resmi pihak kementerian Hal Ehwal Universitas Thailand, ialah College of Islamic Studies (CIS) Prince of Songkhla Universitas, Kampus Patani, Universitas Pathoni dan Akademik Islam danPerguruan Bahasa Arab Universitas Naratiwas Rachanakrin di wilayah Naratiwat.

\section{Universitas Songkla Nakharin}

Prince of Songkla University kampus Pattani dahulu dikenal dengan Universitas Selatan Thai, nama yang diberikan bersempena dengan Seri Paduka Baginda Raja Anggun Duli Yang Maha Mulia Somdej Chao Fa Mahidol Adulyadej Kromma Luang Songkla Nakharin sebagai penghormatan kepada baginda semenjak September 1967. Sejarah pada 12 Maret 1968 bahwa Parlemen Thailand telah meluluskan Universitas Songkla Nakharin dan berkuatkuasa pada 13 Maret, tarikh tersebut dianggap sebagai Hari Yayasan Universitas Songkla Nakharin. Tujuan pendiriannya untuk membangunkan wilayah selatan Thailand berikutan selaras dengan rencana pendidikan dan dasar pembangunan pertumbuhan ekonomi masyarakat, membawa keharmonian dan kesaksamaan kepada rakyat serta sebagai sumber perkhidmatan akademik untuk masyarakat kota dan kampung (Prince of Songkla Universitas).

Pada 21 sehingga 23 Desember 2011, Kolej Perguruan Islam Universitas Songkla Nakharin Islam telah mengadakan Persidangan Perguruan Islam Internasional, yang membahas topik "Peranan Perguruan Islam di Zaman Globalisasi" yang bertujuan untuk menyediakan platform perkongsian ilmu pengetahuan dan saling bertukar pengalaman berhubung kurikulum pendidikan Islam menuju transformasi dunia pendidikan Islam modern, dan perkara yang dalam persidangan ini juga untuk membincangkan kurikulum perguruan Islam, seminar ini diadakan buat kali pertamanya di Thailand (www.manager.co.th).

Peranan dan pembangunan kurikulum perguruan Islam ini adalah kolej yang pertama didasarkan sebagai institusi perguruan tinggi di negara Thai. Sementara itu, merupakan badan yang penting dan memberi tumpuan dalam menyelesaikan masalah masyarakat setempat dan pusat khidmat ilmu Islam 
yang menjalankan kajian dan penyelidikan Islam untuk membangun masyarakat (Boonsom Siribamrungsuk), dengan peningkatan yang berterusan kualiti pendidikan Islam dijangka menyumbang kepada tunggak pembangunan watak seorang Muslim yang pintar, berakhlak mulia, dan produktif. Penyelesaian masalah kadang-kadang dipandang sebagai salah satu bentuk pengetahuan yang tertinggi (Hasan Langgulung, 1997). Visi Universitas ialah "Kecemerlangan Universitas berteraskan budaya serta membangun masyarakat", adapun, misi Universitas Songkla Nakharin kampus Pattani (www.pn.psu.ac.th)ialah seperti berikut :

- Membangunkan masyarakat berdasarkan prinsip latar belakang dan ekonomi dalam berbagai budaya, dan menggunakan akses dan kemudahan untuk pembelajaran dan menghasilkan manfaat dari sumber pengetahuan yang terdapat di Universitas.

- Untuk membina kepakaran dan mengambil peranan utama dalam bidang perguruan selaras dengan potensi setempat dan membina hubungan rangkaian secara global.

- Untuk melahirkan lulusan yang berintelek yang terpadu dan menggunakan pengetahuan berdasarkan pengalaman dan praktik, kebijaksanaan, kuat dan cekapsebanding dunia luar.

Universitas Songkla Nakharin Kampus Pattani mempunyai tujuh fakultas ialah; fakultas pendidikan, fakultas kemanusiaan dan sains sosial, fakultas sains dan teknologi, fakultas kegunaan seni halus, fakultas sains komunikasi, fakultas sains politik dan fakultas kejururawatan, adapun, kolej ialah kolej perguruan Islam dan institusi ialah institusi perguruan pascasarjana. Untuk menjamin pelaksanaan perjalanan perguruan di Universitas Songkla Nakharin Kampus Pattani bersedia dan berjalan lancar dalam menejemen pembangunan serta struktur bangunan sentiasa bersedia, dan menjadi perkara dasar dan utama. Universitas Songkla Nakharin Kampus Pattani mempunyai kemudahan dasar bangunan dan pejabat, untuk bangunan yang terdiri dari; Bangunan Utama Pemerintahan Am, bangunan perkhidmatan pendidikan setiap fakultas, bangunan bagian hal ehwal pelajar, bangunan unit pembangunan dan bangunan pelan perancang dan strategi. Dan, bangunan pejabat dan institusi terdiri dari beberapa unit pejabat ialah; Pejabat presiden, institusi sumber akademik, institusi perkembangan dan pendidikan, bangunan perpustakaan am Universitas, institut penyelidikan dan kajian Kebudayaan Yayasan Princess Galyani Vadhana dan bangunan institusi halal.

\section{Kolej Perguruan Islam}

Perguruan sarjana muda perguruan Islam dimulai pada 31 Desember 1989 sebagai akademik dan pusat penyelidikan pembangunan dan perkhidmatan 
masyarakat. Potensi sesebuah kolej adalah untuk melahirkan lulusan dalam bidang Islam. Pada tahun 1972, dimulai peletakan batu dasar pendirian bangunan kolej, setelah mengadakan seminar, forum dan pameran perguruan. Pada tahun 1974 Syeikh Muhammad Tawfiq Uwaidah, sekretaris persidangan Islam Kaherah, bersama dengan Prof. Mohsin Abdul Rahman Abu Sida Universitas al-Azhar, datang berkunJunig dan mengadakan kerjasama dalam program perguruan Islam, dan cadangan untuk membuka program perguruan bahasa Arab dan perguruan Islam serta memberi dana sebanyak 500,000 Bath. Sebagai permulaan projek tersebut (Univesiti SongklaNakharin (1979); Ibrahim Narungraksakit \&Numan Hajimasae, (2010).

Setahun kemudian, Syeikh Hasan al-Tohamy sekretaris persidangan negara-negara Islam sedunia Jeddah datang membuat lawatan ke Universitas Songkla Nakharin Pattani dan pihak Kerajaan Abu Dhabi bersetuju untuk memberi sumbangan dalam program bantuan projek pendidikan Islam di Selatan Thai sebanyak 80 juta Bath dengan meminta supaya kerajaan Thailand melantik ahli jawatankuasa rangka kerja pembangunan projek pelaksanaan pembinaan, serta cadangan untuk mengadakan musyawarah badan-badan Islam, dengan sebab kekurangan tenaga dan kata sepakat dari pihak menejemen dan badan-badan yang bertanggungjawab di peringkat pelaksanaan serta beberapa masalah yang tidak bisa ditangani dengan baik, maka bantuan tersebut terkendala terpaksa ditarik kembali (Universitas SongklaNakharin,1984).

Projek pembangunan kolej perguruan Islam merupakan projek ulung kali dalam sejarah kerajaan Siam, projek yang peruntukan anggaran skala besar di bawah rancangan dan perencana Universitas dan satu-satu perencana pembangunan berdasar peraturan pemerintah dibawah rencana yang kelima (1983-1985M) di bawah unit pembangunan dan kemajuan ekonomi dan sosial nasional yang bertujuan menjadi pusat perguruan agama yang menyeluruh dan setiap peringkat sehingga ke tahap perguruan tinggi (www.cis.psu.ac.th), dalam rangka pelaksanaan pembangunan dan pendirian projek ini pihak senat Universitas dan ahli majlis tertinggi Universitas telah setuju dan meluluskan projek tersebut pada persidangan yang ke-108 (7/1985) pada tarikh 28 Juli 1985 serta mendapat muafakat dari lembaga perguruan tinggi dalam persidangan ke$11 / 1985$ pada 8 November 1985, dengan memberi persetujuan untuk dibangunkan sebuah kolej perguruan Islam sejalan dengan perlembagaan Universitas dan menteriperguruan tinggi telah meluluskan pada 15 April 1986 (Universitas Songkla Nakharin-Pattani,1985).

Dewan rakyat akan bersidang rancangan undang-undang dan persetujuan raja untuk meluluskan projek pembangunan kolej Islam. Walau bagaimanapun, dengan bijaksana kerajaan Thai yang melihat jumlah pelajar yang tamat perguruan sijil Thanawi dari pusat dan madrasah pondok sekolah agama rakyat atau swasta semakin meningkat lagi, untuk menampung kemasukan pelajar tersebut ke peringkat perguruan yang lebih tinggi diploma dan ijazah, maka, pada 31 Desember 1991, dimulai operasi untuk pendaftaran 
periode pertama peringkat sarjana muda perguruan Islam yang dicadangkan oleh unit ekonomi dan sosial budaya bahwa kolej perguruan Islam akan dijadikan sebagai pusat perguruan Islam dirantau ini.

Pihak Universitas bersetuju dengan menjadikan perguruan Islam di bawah fakultas kemanusiaan dan sains sosial, selepas membentuk dan membina kurikulum pendidikan Islam di peringkat sarjana muda dengan mendapat kelulusan dari pihak majlis tertinggi Universitas dengan sokongan ahli kabinet serta diluluskan anggaran dan surat edaran pada 31 Desember1991, (www.cis.psu.ac.th). Visi kolej ialah "Kolej Perguruan Islam sebagai institusi pendidikan tinggi yang unggul di rantau ini dan dunia Islam berteraskan penyelidikan" Adapun, misinya ialah pusat: i. Untuk membangun dan memajukan masyarakat setempat berdasarkan prinsip Islam, ii. Sebagai pusat kajian dan penyelidikan perguruan tinggi Islam di rantau ini, iii. Untuk membangunkan pusat kajian dan penyelidikan di timur tengah, iv. Sebagai pusat perkembangan modal manusia dan pusat bahasa, v. Serta pereka membina kurikulum perguruan Islam setaraf Internasional, vi. Integrasi perguruan Islam untuk membina intelektual Islam yang bermoral tinggi, vii. Mendidik masyarakat berakhlak mulia dan menjaga budaya berdasarkan Islam dan akhirnya, ix. Penyebaran dan dakwah budaya yang mulia dalam kerangka Islam. Adapun,tujuan kolej ialah untuk:-

- Melahirkan lulusan yang berilmu mampu menjalankan kehidupan, berakhlak mulia, mempunyai kemahiran, ada potensi dan berjiwa masyarakat.

- Mengembangkan penyelidikan yang berguna dalam bidang perguruan Islam, perguruan Timur Tengah dan dunia Islam serantau.

- Menjaga budaya yang selaras Islam.

- Mewujudkan sistem pemerintahan dan menejemen yang cekap, telus dan bisa diuji.

- Pembinaan kurikulum Islam setaraf Internasional keperingkat dunia.

- Bekerjasama dengan mana-mana badan kearah kecemerlangan dalam pendidikanIslam.

- Pemeliharaan dan penyebaran adat istiadat dan budaya yang sejalan dengan syariah.

Perjalanan kolej untuk menjayakan visi dan misi Universitas untuk memenuhi tuntutan masyarakat menurut potensi dan kesediaan. Kolej Perguruan Islam juga telah mampu menghasilkan lulusan untuk berkhidmat kepada masyarakat, memperluas bidang kajian dan penyelidikan baru, perkhidmatan ilmu kepada masyarakat, menjaga budaya, perkara ini dapat direalisasikan dengan adanya gagasan struktur menejemen konkrit serta pelan strategi yang terancang, struktur Kolej Perguruan Islam Universitas Songkla Nakharin Pattani dapat 
dibagi kepada tiga bagian adalah: i. Pejabat pemerintahan dan menejemen, ii. Unit khidmat masyarakat, dan iii. Pusat menejemen akademik perguruan Islam.

Pelaksanaan pelan strategi Kolaj semenjak tahun 1981 sehingga kini adalah seperti berikut: Pada tahun 1981, dimulai ijazah sarjana muda dalam bidang perguruan Islam di bawah Fakultas Kemanusiaan dan Sains Sosial, pada tahun 1994, dimulai perguruan Ijazah Sarjana Muda dalam bidang Perguruan Islam, pada tahun 1997, dimulai perguruan Ijazah Sarjana Muda dalam bidang undang-undang Islam, pada tahun 1998, dimulai Ijazah Sarjana Bidang Perguruan Islam. Pada tahun 2000, dimulai Ijazah Sarjana Muda dalam bidang Perguruan Islam (Program Bahasa Arab), pada tahun 2002, dimulai projek pengukuhan bidang perguruan Islam, pada tahun 2002 juga, dimulai perguruan Ijazah Sarjana Muda, bidang ekonomi dan menejemen dalam Islam, pada tahun 2004, dimulai projek kajian strategi wilayah berhubung perguruan Islam, pada tahun 2005, dimulai perguruan sarjana muda Bidang Perguruan Timur Tengah, pada tahun 2006, dimulai perguruan doktor (Ph.D), bidang Perguruan Islam dan pada tahun 2007, permulaan perguruan sarjana muda bidang PerguruanIslam dalam Program Internasional.

Pelaksanaan operasi program perguruan Islam di Universitas selaras dengan rencana pembangunan perencana kerajaan Thai yang telah diluluskan menurut rencana pembangunan dan kemajuan ekonomi dan sosial negara ke-4, sehubungan dengan pembangunan perguruan dan pendidikan di peringkat perguruan tinggi, telah dilantik ahli jawatankuasa perangka dan pembinaan kurikulum pendidikan dan perguruan Islam di peringkat perguruan tinggi atau sarjana muda Degree Islamic Education, dengan arahan dari pucuk pimpinan Universitas pada no. surat edaran 337/2519 serta senarai sepuluh dari intelektual Islam dan profesional dalam bidang ilmu perguruan Islam dan tiga orang penasihat (www.cis.psu.ac.th), oleh sebab ahli jawatankuasa kerangka pembinaan kurikulum belum bersedia serta kepakaran kepada bidang ilmu terhad dan juga tidak ada kemudahan menjadi perjalanan terbantut seketika hingga pada bulan Januari 1979M, Prof. Madya Anan Okaroth mencadangkan penambahan ahli jawatankuasa lagi sebanyak empat orang dan penambahan lagi dua orang pada bulan September tahun yang sama yaitu Tuan Wan Husin Madeha' dan Tuan Dalomnoor Baka, mereka yang memainkan peranan dan pendiri kepada pembangunan dan pembinaan kurikulum yang pertama terdiri dari tiga orang yaitu Assistant Professor atau Profesor Madya Anan Okaroth, Tuan Wan Husin Madeha'dan Tuan Dalomnoor Baka (Ibrahim \& Numan, 2010).

Ahli jawatankuasa pelaksanaan pendirian pembangunan dan pembinaan kurikulum ada mencadangkan supaya mengadakan musyawarah di Bangkok disertai perwakilan dari Majlis Syeikh Islam Penasihat Diraja yaitu Dr. Imran Malulim turut serta dalam pembahasan dan di antara isu cadangan usul ialah penukaran nama kurikulum dari Kurikulum Pendidikan Islam (Islamic Education) kepada Kurikulum Perguruan Islam (Islamic Studies), cara 
pelaksanaannya menurut rancangan perencana pengajaran mata pelajaran perguruan Islam sejalan dengan mata pelajaran teori falsafah dan adat istiadat budaya (Ibrahim Narung Raksakit \& Numan Hajimasae, 2010).

Pada tahun 1979, Fakultas Sains Kemanusiaan dan Sosial Universitas telah menghantar wakil untuk membuat penjelasan dan uraian berhubung kurikulum perguruan Islam di Pejabat Pelajaran Perguruan Tinggi Pusat di Bangkok, mereka termasuk Tuan Pann Yuanhein, Tuan Manok Yudin, dan Tuan Dunmanor Baka, setelah persetujuan dan kata sepakat meluluskan kurikulum perguruan Islam di peringkat sarjana muda dari pihak ahli jawatankuasa tertinggi Universitas pada 24 Desember 1980, dan pada bulan April 1981, ahli jawatankuasa kerajaan karachakan pholareang mengakui ijazah pelajar yang berhasil menyelesaikan sukatan kurikulum tersebut, sukatan kurikulum perguruan Islam di peringkat sarjana muda pada tahap permulaan operasi di bidang perguruan Islam di bawah fakultas sains kemanusiaan dan sosial Universitas, selepas itu peringkat permohonan peruntukan tambahan dan anggaran tambahan untuk pelaksanaan dan penerusan program tersebut dapat berjalan lancar (Ibrahim \& Numan, 2010).

Pembangunan kemajuan tahap ke-dua ialah: perencana pembangunan kemajuan untuk menjadikan sebuah kolej perguruan Islam, secara resminya pada tahun 1982M, apabila pihak Universitas mengeluarkan surat edaran resmi memberi arahan dan pada 29 Oktober 1982, melantik ahli jawatankuasa pemerintahan dan pelaksanaan projek pendirian pusat perguruan Islam bertujuan mengkaji dan menyelidik serta merancang pelaksanaan projek pendirian pusat perguruan Islam dan didaftarkan projek tersebut sebagai projek pembangunan kemajuan Universitas perencana ke-6, dan pada tahun seterusnya, Universitas ada mengeluarkan surat edaran resmi arahan perlantikan ahli jawatankuasa projek pembangunan pendirian Pusat Perguruan Islam dan majlis ahli jawatankuasa perancang dan pelaksanaan Pusat Perguruan Islam, bertujuan penyelidikan dan kajian penyesuaian serta pelaksanaan dapat melalui dengan jaya dan berjalan lancar menurut apa yang dirancang dan diharapkan menurut pelan perencana pembangunan kemajuan ekonomi dan modal manusia peringkat kebangsaanke-5,(Universitas Songkla Nakharin, 1981).

Untuk mencapai tujuan dan merealisasi tujuan tersebut, pihak Universitas telah mengadakan seminar ilmiah untuk mengumpulkan pandangan dan pemikiran yang bernas dalam usaha membangun serta membina kerangka objektif, tujuan, tujuan, misi, visi, cara dan kaedah, serta adat etika dalam pendirian pusat perguruan Islam. Pada 27 hingga 29 Mei 1983 pesertanya yang membentangkan seminar terdiri dari Sekretaris Majlis Keamanan Kebangsaan yang membentangkan tajuk "Perguruan Islam dan Keamanan Negara" dan perwakilan dari Sekretaris Majlis Ahli Jawatankuasa Ekonomi dan Modal Manusia, menghuraikan prosedur dan undang-undang pendirian dan pembangunan pusat perguruan Islam menurut rancangan perencana pembangunan dan kemajuan ekonomi dan modal manusia ke-5 pada tahun1 
982-1987M (Universitas Songkla Nakharin,1981). Dan juga ikut perwakilan dari pihak kerajaan dan jabatan-jabatan, agensi-agensi dan pihak LSM yang ada kepentingan dengannya, pada akhir seminar dapat memutuskan pendirian seperti berikut: i. pelaksanaan Pusat Perguruan Islam berdasarkan Islam sebagai garis panduan untuk menyahut tuntutan dan kehendak masyarakat setempat dan komuniti Muslim, ii. Pusat Perguruan Islam dalam pendiriannya bertujuan supaya Universitas Songkla Nakharin Pattani dapat menghubung dua hala dengan mana-mana negara khususnya negara-negara Islam dalam membangun bersama dan menjalankan kerjasama dalam bidang pendidikan, perguruan, intelektual ilmuwan Islam, agama serta budaya yang selaras dengan undangundang negara, dan iii. Pusat Perguruan Islam dalam pendiriannya untuk menjaga keamanan terutama dalam politik negara dan membangun ekonomi dan modal manusia melalui piagam serta undang-undang keamanankerajaan (Ibrahim \& Numan, 2010). Sepanjang tahun 1982 hingga 1984, Universitas Songkla Nakharin Kampus Pattani, melaksanakan program penyelarasan setiap jabatan dan majlis ahli jawatankuasa pembangunan dan pelaksanaan bersama Unit Pembangunan Pelan Kemajuan Ekonomi (UPPE) dan Pembangunan Modal Manusia (PMI), turut membahaskan perkara-perkara yang membangkit seperti; nama institusi, yang sesuai di antara 'Pusat' atau "Institusi" dan pada musyawarah kali ke-108 (7/2527) pada 28 Juli 1982, telah membahas dan berbincang bersetuju supaya pendirian atas nama "Institusi Perguruan Islam", seterusnya, keputusan tersebut akan dicadangkan ke AJK tertinggi Universitas untuk dipertimbangkan (UPS Pattani, 1988; Ibrahim \& Numan, 2010).

Dalam catatan surat edaran no. TM.1201/5757 Universitas Songkla Nakharin Kampus Pattani pada 24 Agustus 1971, ada cadangan memohon pendirian institusi perguruan Islam di kampus Pattani, tujuannya untuk melahirkan sarjana muda dalam bidang perguruan Islam dan keilmuan Islam, dan juga sebagai pusat kajian dan penyelidikan berhubung komuniti masyarakat beragama Islam. Perkara tersebut, dirujuk kepada pejabat peruntukan kewangan Universitas, dan peruntukan tersebut dibahaskan sekali lagi dari kalangan Ahli Jawatankuasa Tertinggi Universitas Songkla Nakharin dalam majlis yang diwakili Tuan Pann Yuanghae, timbalan rektor Universitas Songkla Nakharin kampus Pattani dan Tuan Dulmanon Baka ialah penyelaras projek pendirian Kolej Perguruan Islam, selepas musyawarah mempertimbangkan projek tersebut, maka, keputusan dari musyawarah itu, pihak ahli jawatankuasa bersetuju projek pendirian tersebut dan melantik pihak bertanggungjawab dalam hal itu, pada musyawarah kali ke-3/1985 yang bertarikh 14 Maret 1985, Kementerian Perguruan Tinggi telah meluluskan pendirian kolej Perguruan Islam pada 10 April 1985M setaraf fakultas di bawah Universitas Songkla Nakharin Pattani (Universitas Songkla Nakharin, 1988).

\section{Pentadbiran Kolej Perguruan Islam}


Dalam jangkau usia 26 tahun, pendirian Kolej Perguruan Islam Universoti Songkla Nakharin Pattani semenjak 1990 hingga 2016 bukan tempoh masa yang singkat untuk mengekalkan dan mampu melahirkan lulusan sehingga 20 angkatan yang berhasil menamatkan sarjana muda perguruan Islam di setiap pengkhususan dan bidang perguruan Islam. Ini menjadi mercu tanda kejayaan sesebuah institusi perguruan. Untuk Kolej Perguruan Islam USN Pattani, jawatan dekan sepanjang tempoh ini diambil alih seramai empat orang dekan atau jawatan pengarah dalam tempoh masa lima penggal, adapun yang memegang jawatan sampai dua panggal ialah Dr. Ismail Ali. dekan pertama ialah, Rahim Niyundicha, penggalnya dimulai pada 1 Januari 1990 hingga 31 Juni 1990, kedua ialah, Assoc. Dr. Ismail Ali, juga untuk panggal kedua dan ketiga yang dimulai pada 1 April 1990 hingga 31 Maret 1994 dan 1 April 1994 hingga 14 Juni 1998, direktor ketiga ialah Assoc. Dr. Hassan Madman pada penggal keempat dimulai pada 15 Juni 1998 hingga 31 Juli 2002, dan penggal keenam dijawat jawatan oleh Assoc. Dr. Ismail Ali juga dimulai 1 Agustus 2002 hingga 31 Juli 2010 dan Dekan keempat ialah Dr. Yusuh Talib sebagai panggal ketujuh dimulai 1 Agustus 2010 hingga sekarang.

\section{Penutup}

Secara keseluruhannya, penemuan-penemuan dari kajian serta penyelidikan berhubung aspek sejarah pendidikan memperlihatkan kaitan dengan skop kajian. Dari dapatan tersebut, kajian ini akan menjadi panduan dan rujukan penting untuk pusat-pusat Islam dan madrasah serta ma'had dan institusiinstitusi perguruan tinggi kolej serta Universitas Islam di Thailand. Lantaran itulah, kajian ini juga dilaksanakan dengan hasrat untuk membantu meningkatkan dan menambah bahan sejarah seterusnya melahirkan generasi penuntut yang menguasai sejaarah Islam secara ilmiah. Mogo-moga diberkati Allah S.W.T atas semua usaha.

\section{Daftar Pustaka}

al-Quranal-Karim

Calerm Kiat Khunthongpech. (1997) Kan Taton Nayobai Ratthaban Nai Si

ChangwatPhaktai Khong Prathetthai Doikannam Khong H.Sulong Abd.

Qadir, Mitraphap: Patani.

Chapakia, Ahmad Omar. (2000). Politik Thai dan Masyarakat Islam di Selatan

Thailand, Ph.D Tesis, Kedah: Pustaka Darussalam \& RM Multimedia

Publishing.

Hasan Langgulung. (1997). Dasar-dasar Pedidikan Islam,(Cet.2) Kuala

Lumpur : Dewan Bahasa dan Pustaka.

Hassan Langgulung.(1988). Pendidikan Islam menghadapi abad ke-21. Jakarta:

Pustaka al-Husna. 
Hisan, Muhammad dan Nadiyah Jamal al-Din. (1984). Madaris al-Tarbiyah fi al-Hadarah al-Islamiyyah. Kaherah: Dar al-Fikr al-'Arabi.

Ibarahim Narongraksakhet dan Rakan-rakannya.(2010).

Ibn Kathir, Abu al-Fida Ismail bin Umur. (1992) al-Bidayah wa al Nihayah. Kaherah: Daral-Hadith.

Kolej Perguruan Islam (1405 H) Laporan Seminar Akademik Islam Bertema: Islam dan Cara Hidup, Universitas Songkla Nakarin Pattani.

Maksidi, G. (1981a). Hambalite Islam. Studies on Islam. Edited by Merlin L. Swartz. New York: Oxford Universitas Press.

Maksidi, G. (1981b). Institution of Leaning and Religions Movements, in studies on Islam.Edited by Merlin L.Swartz. NewYork: Oxford University Press.

Maksidi, G. (1981b). The Rise of Colleges; Institution of Leaning in Islam and the West. Edinburgh University Press.

Mursi M.M. (1974). al-Tarbiyah al-Islamiyah: Usulubuha wa-tatawwuruha fi al-Bilad al-'Arabiyah. Kahirah: Alamal-Kutub.

Mohd. Zamberi A. Malek. (1994). Patani dalam Peradaban Melayu, Kuala Lumpur: Dewan Bahasa dan Pustaka.

Mohd. Zamberi A. Malek. (1993). Umat Islam Patani, Sejarah dan Politik, Shah Alam: Hizbi Poblisher.

Nathan Sehachner. (1962) Nathan Sehachner, The Founding Fathers', Capricorn Books, NewYork.

Nik Anuar Nik Mahmud (1999) Sejarah perjuangan Melayu Patani (17851954) Published 2000 by Penerbit UKM

Nik Anuar Nik Mahmud @ Mohd Zamberi A.Malek (2007) Peradaban dan Sosio-Politik Melayu Patani. Kuala Lumpur: Persatuan Sejarah Malaysia Cetak Jitu SdnBhd.

Noor Hisham, Md Nawi (2011). Konseptualisasi Semua Kurikulum Pendidikan Islam. Tanjong Malim, Perak: Penerbit Universitas Pendidikan Sultan Idris.

Nurazmallail Marni \& Zulkiflee Haron. (2008) Institusi Perguruan Syariah \& Sains. Skudai, Johor DarulT a'zim: Muafakat JayaPercetakan SDN.BHD.

Price of Songkla Universitas Pattani (1979).

Price of Songkla Universitas Pattani (1981)

Price of Songkla Universitas Pattani (1983) Seminar: Raingan Perakchum

Sammana phea Chattam Sung Islamsuksa,Mahavitlalai Songkhla Nakharin Pattani.

Price of Songkla Universitas Pattani (1984)

Price of Songkla Universitas Pattani (1985)

Price of Songkla Universitas Pattani (1988)

\section{RujukanLain}


Wardah, Vol.18, No.2, 2017

Abdulrasyid Bin Hassan

Mahsidi Salae

Muhammad Azhar Zailani

Ghazali Darusalam

College Islam Studies price of Songkla University www.cis.psu.ac.th/fathoni/lesson/edu.../lesson9.htm price of Songkla University

www.pn.psu.ac.th/webEng/faculty.php

Muslim di Thailand

www.muslimtrat.com

Menejemen Pendidikan di Thailand

www.manager.co.th/Home/preload_493.html 